\title{
In vitro mature embryo culture protocol of einkorn (Triticum monococcum ssp. monococum) and bread (Triticumaestivum) wheat under boron stress
}

\section{Ferdi Ağıl}

Bolu Abant Izzet Baysal Universitesi Fen Edebiyat Fakultesi

Mehmet Örgeç

Bolu Abant Izzet Baysal Universitesi Fen Edebiyat Fakultesi

Fatma Pehlivan Karakaş

Bolu Abant Izzet Baysal Universitesi Fen Edebiyat Fakultesi

Sandeep Verma Kumar

Sage University

Nusret Zencirci ( $\sim$ nzencirci@gmail.com )

Abant Izzet Baysal Universitesi https://orcid.org/0000-0003-3460-7575

\section{Research Article}

Keywords: Einkorn, Bread, Mature embryo, Callus, Boron stress

Posted Date: June 3rd, 2021

DOI: https://doi.org/10.21203/rs.3.rs-501998/v1

License: (c) (i) This work is licensed under a Creative Commons Attribution 4.0 International License. Read Full License 


\section{Abstract}

Mature embryos of einkorn (Triticum monococcum ssp. monococcum) and bread (Triticum aestivum) wheat were used for callus induction on media containing four $\left(0,1,2\right.$ and $\left.4 \mathrm{mg} \mathrm{L}^{-1}\right)$ different doses of 2,4-D and dicamba supplemented with under five (0,6.2, 12.4, 24.8, and 37.2 mg $\mathrm{L}^{-}$

$\left.{ }^{1}\right)$ different boron stresses. The obtained callus was transferred to culture media with three $\left(0,0.5\right.$, and $\left.2 \mathrm{mg} \mathrm{L}^{-1}\right)$ different BAP doses with five boron stresses for regeneration. The heaviest callus weight in einkorn wheat was in culture media with $1 \mathrm{mg} \mathrm{L}^{-1}$ dicamba and $6.2 \mathrm{mg} \mathrm{L}-1$ (3.71 \pm $0.13 \mathrm{~g})$. Bread wheat had the heaviest callus weight on culture media with $4 \mathrm{mg} \mathrm{L}^{-1}$ dicamba and $12.4 \mathrm{mg} \mathrm{L}^{-1}(3.46 \pm 0.40 \mathrm{~g})$. Callus diameters were observed as the highest in culture media with $1 \mathrm{mg} \mathrm{L}^{-1}$ and $12.4 \mathrm{mg} \mathrm{L}^{-1}(1.10 \pm 0.31)$ for einkorn and $4 \mathrm{mg} \mathrm{L}^{-1}$ dicamba with $6.2 \mathrm{mg} \mathrm{L}^{-1}$ boron $(1.22 \pm 0.27 \mathrm{~cm})$ for bread wheat. Regeneration capacity was highest in control group with $6.2 \mathrm{mg} \mathrm{L}^{-1}$ for both wheat genotypes (einkorn, $71.33 \% \pm 11.78$ and bread, $65.33 \% \pm 10.80)$. The highest plantlet numbers were in only $2 \mathrm{mg} \mathrm{L}^{-1} \mathrm{BAP}(2.92 \pm 0.88)$ for einkorn wheat and $0.5 \mathrm{mg} \mathrm{L}^{-}$

${ }^{1}$ BAP supplemented with $6.2 \mathrm{mg} \mathrm{L}^{-1}$ boron $(3.71 \pm 1.12)$ for bread wheat. This indirect regeneration protocol using mature embryos of einkorn and bread wheat under boron stresses may be useful for wheat breeding studies.

\section{Key Message}

The embryo tissues of different types of wheat have provided to develop in vitro conditions by applying boron stress. 2,4-D and dicamba, which are different auxin types, played an effective role in the formation of callus.

\section{Introduction}

Wheat is in the Triticeae tribe of the Poaceae family. It has a major role in all around the world not only for a nutrient source for many people but also a feed source for animals. It is grown worldwide on 215.9 million ha, which is approximately $30 \%$ of the total agricultural land, results in a production of 765.7 million tons in 2019 (FAO, 2020).

The diploid $\left(2 n=2 x=14, A^{m} A^{m}\right)$ cultured einkorn (Triticum monococcum ssp. monococcum) wheat is one of the first cultivated wheat. It is derived from T. boeticum in the Karacadağ mountain in Southern Eastern Turkey, about 10,000 to 13,000 years ago (Peng et al. 2011). Einkorn contains high amounts of carotenoids, antioxidants, vitamins (B and E) and minerals such as zinc, iron, and copper (Suchowilska et al. 2012; Şahin et al. 2018; Yaman et al. 2019; Pehlivan-Karakaş et al. 2020). Its protein content ranges between 16.00 - 28.50\% (Hammer et al. 1996). Moreover, einkorn wheat has also useful genetic traits such as resistance to biotic/abiotic stresses (Abdel-Aal et al. 1995). These genetic traits may be advantageous in wheat breeding programs. The other important cultured wheat species are tetraploid $(2 \mathrm{n}=4 \mathrm{x}=28, \mathrm{AABB})$ durum $(T$. durum) and hexaploid $(2 \mathrm{n}=6 \mathrm{x}$ $=42$, AABBDD) bread ( $T$. aestivum L.) wheats. These two are the most grown and consumed wheat species today.

Global crisis such as Covid-19 pandemic showed that crop production such as wheat, rice maize etc. is highly strategic for food supply and safety. Humankind may face to a global warming crisis in near future. Global warming may, unfortunately, worsen climatic conditions, deteriorate agricultural estate conditions, decrease quality and production of the crops. To feed huge amount of human population today, new approaches should be developed to improve high yielding and biotic/abiotic stress resistant crops (Örgeç et al. 2021).

Boron is an essential micro element for plant growth and development. Plants take boron in boric acid form from the soil and groundwater. Naturally occurring boundaries, fertilization, and irrigation may cause boron availability in the soil (Nable et al. 1997). Boron toxicity is a serious abiotic stress in arid and semi-arid regions around the world (Kalaycl et al. 1998) and it may be the one of the prevalent stresses in near future due to drought. In boron deficiency, properties such as growth rate, yield, and quality in plants are decreased. On the other hand, the boron excess in the soil causes toxicity in plants and leads harmful effects on photosynthesis, stem cell differentiation, expansion of the cell wall, and deoxidative damage (Cervilla et al. 2007). Wheat and barley are, in particular, shown to be prone to excess boron in the soil (Gupta et al. 1985) and the yield decreases and quality worsens (Cartwright et al. 1986).

Genetic transformation is a good approach to improve biotic/abiotic stress resistant wheat cultivars. Tissue culture is, in that context, a key step for a successful genetic transformation and for a productive wheat breeding. Tissue culture success can be affected by many factors such as explant type, media compositions, genotype or growth conditions, etc. Any tissue culture application may show different responses even to different wheat cultivars (Jabeen et al. 2016). It is important to emphasize that an effective and applicable tissue culture protocol is needed for each wheat species in wheat improvement programs. Tissue culture systems for various species prefer mostly immature embryos as an explant. Although immature embryo has higher callus production and regeneration, it has some restrictions such as longer generation time or intensive workload (Yang et al. 2015; Mahmood and Razzaq, 2017).

Considering all these points, we focused, in this study, on determining an appropriate and effective tissue culture protocol for einkorn and bread wheat varieties by testing mature embryos under five different boron concentrations and two different auxin hormones in MS basal medium. Furthermore, four different 2,4-D and Dicamba doses for callus induction, five different boron concentrations, and three doses of BAP for indirect regeneration were experienced. 


\section{Material And Methods}

\subsection{Seed Source}

Seben / Bolu 2016 harvest of mature einkorn wheat (IZA: Triticum monococcum subsp. monococcum) embryos and Central Research Institute for Field Crops (CRIFC) provided bread wheat (Triticum aestivum L. cultivar: Tosunbey) were used as explant sources for callus induction and indirect regeneration.

\subsection{Seed Sterilization}

De-hulled einkorn and bread wheat seeds were washed by five drops Tween 20 (Merck, Darmstadt, Germany supplemented) $100 \mathrm{~mL}$ distilled water for one minute, then, disinfected with $40 \%$ commercial bleach (4.6\% NaClO; Domestos, Istanbul, Turkey) with a magnetic stirrer for 15 min in a laminar air flow. Seeds were washed with sterile water to remove chemicals from seeds at the end (Örgeç et al. 2018).

The seeds were, after seed sterilization, kept in a sterile pure hot water bath at $33^{\circ} \mathrm{C}$ for approximately $2-3$ hours for easy embryo extraction (Özgen et al. 1998).

\subsection{Callus Induction}

Excised einkorn and bread wheat mature embryos were used as explants for callus induction. Callus induction media composed of $4.4 \mathrm{~g} \mathrm{\textrm {L } ^ { - 1 }} \mathrm{MS}$ (Murashige and Skoog, 1962) (Duchefa-Haarlem, Netherlands), $30 \mathrm{~g} \mathrm{~L}^{-1}$ sucrose (Merck Darmstadt, Germany), and $8 \mathrm{~g} \mathrm{~L}^{-1}$ agar (Duchefa-Haarlem, Netherlands). Agar were supplemented at five different boron (Sigma-Aldrich-USA) concentrations of 0 to $37.2 \mathrm{mg} \mathrm{L}^{-1}$ (Normally MS media contain $6.2 \mathrm{mg} \mathrm{L}^{-1}$ boron). In addition, four different doses ranging from 0 to $4 \mathrm{mg} \mathrm{L}^{-1}$ of 2,4-D (Sigma-Aldrich, Steinhem, Germany) and Dicamba (DuchefaNetherlands) were added to callus induction media. The $\mathrm{pH}$ of the medium was adjusted to 5.7 to $5.8 \mathrm{using} 1 \mathrm{~N} \mathrm{HCl}$ and $1 \mathrm{~N} \mathrm{NaOH}$ before autoclaving (NC 40M NUVE-Ankara, Turkey) at $121^{\circ} \mathrm{C}$ and $1.06 \mathrm{~kg} \mathrm{~cm}^{-2}$ pressure for $15 \mathrm{~min}$. Subcultures were performed every two weeks.

Detached embryos were placed into callus induction media with scutellum upwards. Each petri dish had 10 embryos in five replicates. The cultures kept in the growth room at $25 \pm 1{ }^{\circ} \mathrm{C}$ under dark conditions for four weeks. Callus weight and diameter of calli formed after 4 weeks were measured and recorded.

\subsection{Plant Regeneration}

Embryogenic calli derived from immature seed of einkorn and bread wheats were carried to regeneration media. The media composed of $4.4 \mathrm{~g} \mathrm{~L}^{-1}$ MS, $30 \mathrm{~g} \mathrm{~L}^{-1}$ sucrose, $8 \mathrm{~g} \mathrm{~L}^{-1}$ agar and five different boron concentrations ranging from 0 to $37.2 \mathrm{mg} \mathrm{L}^{-1}$ supplemented with different BAP (6Benzylaminopurine) (Duchefa-Netherlands) concentrations ranging from 0 to $2 \mathrm{mg} \mathrm{L}^{-1}$ for four weeks. The culture was kept in a growth room at $25 \pm 1^{\circ} \mathrm{C}$ under 16-h light/8-h dark photoperiod. Subcultures were performed every two weeks. At the end of four weeks, regenerated calli in petri were counted for number of plantlets and regeneration capacity.

\subsection{Acclimatization}

The plantlets were washed with sterile water to remove media and then, planted in pots containing of mixture of vermiculate and peat soil at a ratio of 1:3. The plantlets were kept under the same conditions as regeneration process.

\subsection{Statistical Analysis}

The experiment was carried out in a five-replication randomized complete plot design in ten embryo contained petri dishes. Data on callus weight $(\mathrm{g})$, callus diameter $(\mathrm{cm})$, regeneration capacity $(\%)$, and number of plantlets $(\mathrm{n})$ were obtained. Statistical analyses were performed by using SPSS 23.0 program. The analysis of variance (ANOVA) with Duncan post hoc test was used to determine the differences between boron doses, plant growth regulators, and varieties (Düzgüneş et al. 1987; Saha et al. 2017).

\section{Results}

\subsection{Callus Induction}

All mature einkorn and bread wheat embryos were reached $100 \%$ callus induction ratio except control group (Data not shown) (Fig. 1).

\subsubsection{Callus Weight (g)}

Variance analysis showed that there was a significant interaction between wheat genotype/boron dose, wheat genotype/boron stress, and boron stress/hormone on callus weight. However, there was no significant interaction for hormone type, wheat genotype/hormone type and wheat genotype/boron stress/hormone type at $1 \mathrm{mg} \mathrm{L}^{-1}$ hormone dose (Table 3). 
As the seen in Table 4, there were significant interaction between wheat genotype and boron stress and hormone type and boron stress/hormone type for callus weight. On the other hand, wheat genotype/boron stress and wheat genotype/hormone type, and wheat genotype/boron stress/hormone type did not significantly interact at $2 \mathrm{mg} \mathrm{L}^{-1}$ hormone dose.

Boron stress and hormone type and wheat genotype/boron stress and wheat genotype/hormone type had significant interactions on callus weight. Other parameters, however, did not significantly interacted at $4 \mathrm{mg} \mathrm{L}^{-1}$ hormone dose (Table 5).

Among two different auxins, dicamba responded better than 2,4-D for callus weight. One $\mathrm{mg} \mathrm{L}^{-1}$ dicamba significantly produced the highest callus weight $(3.71 \pm 0.13 \mathrm{~g})$ for einkorn wheat cultured on MS medium supplemented with $6.2 \mathrm{mg} \mathrm{L}^{-1}$ boron. On the other hand, for bread wheat, $4 \mathrm{mg} \mathrm{L}^{-1}$ dicamba cultured on MS medium with $12.4 \mathrm{mg} \mathrm{L}^{-1}$, boron responded better than all other hormone doses for the callus weight $(3.46 \pm 0.40 \mathrm{~g})$ ( Table 1).

\subsubsection{Callus Diameter (cm)}

There were significant interactions between wheat genotype and hormone type and wheat genotype/boron stress/hormone type for callus diameter at $1 \mathrm{mg} \mathrm{L}^{-1}$ hormone dose (Table 6). Wheat genotype and hormone type and wheat genotype/boron stress and wheat genotype/hormone type had on the other hand, the significant interactions for callus diameter at $2 \mathrm{mg} \mathrm{L}^{-1}$ hormone dose (Table 7). Wheat genotype and hormone type and wheat genotype/hormone type and wheat genotype/boron stress/hormone type significantly interacted for callus diameter at 4 mg $\mathrm{L}^{-1}$ hormone dose (Table 8).

Dicamba responded better than 2,4-D for callus diameter in both einkorn and bread wheat. One mg L-1 dicamba with $12.4 \mathrm{mg} \mathrm{L}^{-1}$ boron produced the largest callus diameter $(1.10 \pm 0.31 \mathrm{~cm})$ for einkorn wheat (Table 1). Four mg L-1 dicamba with $6.2 \mathrm{mg} \mathrm{L}^{-1}$ boron, on the other hand, resulted in the significantly larger higher bread wheat callus diameter $(1.22 \pm 0.27 \mathrm{~cm})$ than other hormone doses (Table 1).

\subsection{Regeneration}

For shoot regeneration, well-developed callus cultures derived from mature embryos of einkorn and bread wheat cultured on MS media supplemented with 5 different boron and 3 different BAP concentrations was utilized (Fig. 2). After four weeks of culturing, not only all culture media with BAP hormone but also control group were regenerated (Table 2).

\subsubsection{Regeneration Capacity (\%)}

As seen in Table 9 (a-b-c), boron stress and wheat genotype/boron stress significantly interacted on regeneration capacity in control group with 0.5 $\mathrm{mg} \mathrm{L}^{-1}$ and $2 \mathrm{mg} \mathrm{L}^{-1}$ BAP concentrations. Boron stress, on the other hand, significantly interacted for regeneration capacity at the concentration of $0.5 \mathrm{mg} \mathrm{L}^{-1}$ and $2 \mathrm{mg} \mathrm{L}^{-1}$ BAP (Table 9/b-c).

Control group supplemented with $6.2 \mathrm{mg} \mathrm{L}^{-1}$ boron had significantly the highest regeneration capacity with $71.33 \% \pm 11.78$ and $65.33 \% \pm 10.80$ for both einkorn and bread wheat calluses (Table 2).

\subsubsection{Plantlets Number (n)}

Boron stress significantly interacted for number of plantlets at all BAP doses. Wheat genotype/boron stress displayed a significant interaction in control group and $0.5 \mathrm{mg} \mathrm{L}^{-1}$ BAP doses. Genotype did not, however, interacted for number of plantlets in any BAP doses (Table 10).

The highest plantlet numbers existed in $2 \mathrm{mg} \mathrm{L}^{-1}$ BAP without boron $(2.92 \pm 0.88)$ for einkorn wheat and $0.5 \mathrm{mg} \mathrm{L}^{-1}$ BAP supplemented with $6.2 \mathrm{mg}$ $\mathrm{L}^{-1}$ boron $(3.71 \pm 1.12)$ for bread wheat (Table 2$)$.

\section{Acclimatization}

Well-developed plants produced by indirect plant regeneration were detached from media and planted into the mixture of soil and vermiculate (3:1) for a growth in a growth room. After 49 days, bread wheat started to head and at the end of 90 days, well-developed heads were formed (Fig. 2-3). However, einkorn wheat did not head at the end of acclimatization stage.

\section{Discussions}

Optimum media composition was $1 \mathrm{mg} \mathrm{L}^{-1}$ dicamba with $6.2 \mathrm{mg} \mathrm{L}^{-1}$ boron for callus weight, $1 \mathrm{mg} \mathrm{L}^{-1}$ dicamba with $12.4 \mathrm{mg} \mathrm{L}^{-1}$ boron for callus diameter, $0 \mathrm{mg} \mathrm{L}^{-1}$ BAP with $6.2 \mathrm{mg} \mathrm{L}^{-1}$ boron for regeneration capacity, and $2 \mathrm{mg} \mathrm{L}^{-1}$ BAP for plantlet numbers in einkorn (Triticum monococcum ssp. monococcum). On the other hand, optimum media content was $4 \mathrm{mg} \mathrm{L}^{-1}$ dicamba with $12.4 \mathrm{mg} \mathrm{L}^{-1}$ boron for callus weight, $4 \mathrm{mg} \mathrm{L}^{-1}$ dicamba 
with $6.2 \mathrm{mg} \mathrm{L}^{-1}$ boron for callus diameter, $0 \mathrm{mg} \mathrm{L}^{-1}$ BAP with $6.2 \mathrm{mg} \mathrm{L}^{-1}$ boron for regeneration capacity, and $0.5 \mathrm{mg} \mathrm{L}^{-1} \mathrm{BAP}$ with $6.2 \mathrm{mg} \mathrm{L}^{-1}$ boron for plantlet numbers in bread wheat (Triticum aestivum L.). Moreover, dicamba superior than 2,4-D on callus induction for both wheat species.

Plant tissue culture was affected from genotype (Li et al. 2003), plant growth conditions (Hess and Carman, 1998), explant source (Aydın et al. 2011), and culture media (Fennel et al. 1996). In that context, each single plant genotype may have their own specific tissue culture protocol. The most used explant types in wheat tissue culture are immature and mature embryo (Ozgen et al. 1996). In this study, we used einkorn and bread wheat mature embryo which were produced $100 \%$ callus and this result showed similarity previous study which is used ten commercial Indian bread wheat mature embryos for callus induction (Parmar et al. 2012).

Agricultural is adversely affected by abiotic factors including boron all around the world. $20 \%$ of agricultural lands is under the boron toxicity (Hakkı et al. 2007). Boron in lover amounts, on the other hand, is one of the essential elements for plant growth and development (Siddiqui et al. 2013). Previous work has shown that the yield and quality of wheat are improved by supplying the required amount of boron (Wrobel, 2009) under boron lacking conditions. Though, applying excessive boron can decrease shoot length and weight (Marschner, 1995). For all these reason, determination of amount of boron may highly important for efficient plant growth and development.

Plant growth regulators play an important role on embryogenic change, cell cycle regulation, and cell division. Therefore, cytokinins, auxins, their concentrations, and combinations are very important in in vitro studies (Verma et al. 2016). Dicamba, 2,4-D and Picloram are the most used auxin plant growth regulators in wheat and other cereals mature embryo cultures for callus induction (Satyavathi et al. 2004; Filippov et al. 2006). Present study suggested that dicamba was more effective on callus weight and diameters than 2,4-D. Our result agrees with a previous study by Murin et al. (2012) where dicamba was more effective on callus formation at Triticum aestivum L. cv. 'Bobwhite'. Dicamba is more quickly taken by metabolism and, thus, improves callus development. In comparison, 2,4-D avoids accumulation, enzymatic degradation, and remains extremely stable in plant cells (Papenfuss and Carmen, 1987; Moore, 1989; Aydın et al. 2011).

Our results showed that callus weight, genotype and boron stress factors were quite significant in all 2,4-D and Dicamba doses. Genotype variability was important for callus weight. Einkorn callus weighed higher than that of bread wheat. This result is supported by Nasircilar et al. (2006), where five different bread and five durum wheats cultured on callus induction media to compare callus weight. In that study, different genotype calli weighed differently. Both studies indicated that genotype may be an important factor in callus weight. Boron stress is another important factor which is affected callus weight in our study. Einkorn wheat showed the heaviest callus weight under $6.2 \mathrm{mg} \mathrm{L}^{-1}$ boron while bread wheat had it under $12.4 \mathrm{mg} \mathrm{L}^{-1}$. Present study indicated that bread wheat was more resistant to boron stress than einkorn wheat. Moreover, our result found out that callus weight decreased when boron amount increased in the culture media. In the study of Huang and Graham (1990), seven different wheat grains were used to observe effect of six different boron concentrations on cellular and organ level. That study was also parallel with our research. In our report, only 2 and $4 \mathrm{mg} \mathrm{L}^{-1}$ hormone doses were significant on callus weight than other hormone doses. According to our result, 1 mg $\mathrm{L}^{-1}$ dicamba containing $6.2 \mathrm{mg} \mathrm{L}^{-1}$ boron for einkorn wheat and $4 \mathrm{mg} \mathrm{L}^{-1}$ dicamba containing $12.4 \mathrm{mg} \mathrm{L}^{-1}$ boron were the best medium for callus weight. From that point of view, it appeared that dicamba gave better results in wheat mature embryo culture when compared with 2,4-D. Our results supported by Murin et al. (2012) work which 26 wheat cultivars was cultured on callus media containing dicamba and 2,4-D.

Callus size, genotype, and hormone type were quite significant at all 2,4-D and Dicamba concentrations. The bread wheat produced better callus size than einkorn wheat. The different responses of genotypes to callus sizes once again emphasized the importance of genotype selection, as in callus weight. Our results agreed with Zale et al. (2004) where 47 mature wheat cultivar embryos were tested for callus induction and plant regeneration. Another factor that differed significantly was the hormone type. In our study, the best callus sizes were at 1 mg $\mathrm{L}^{-1}$ Dicamba in einkorn wheat and $4 \mathrm{mg} \mathrm{L}^{-1}$ Dicamba in bread wheat. In the light of these results, both our study and previous studies report that Dicamba is more effective than 2,4-D on callus size (Redway et al. 1990; Murin et al. 2012; Kumar et al. 2017). Boron stress did not differ significantly while genotype-hormone type factor was effective at two and four $\mathrm{mg} \mathrm{L}^{-1}$ hormone concentrations on callus size.

The study here showed that the most important factor for regeneration capacity was boron stress in culture media without BAP hormone. Genotypes also did not affect regeneration capacity. Both wheat genotypes had the best regeneration capacity in culture media with 6.2 mg $\mathrm{L}^{-1}$ boron. Yorgancılar and Babaoğlu (2005) made a study by increasing boron stress in different bread and durum wheat genotypes. Their results had the similar results as our study. The result of both studies showed that high amount of boron has adverse effects on the regeneration rates.

Genotype-boron stress factor was significant in culture media containing control group and $0.5 \mathrm{mg} \mathrm{L}^{-1}$ BAP. The best result for both wheat genotypes were in BAP-free media.

The most important factor for plantlets number was the amount of boron in culture media. The best plantlets number was the culture media containing $6.2 \mathrm{mg} \mathrm{L}^{-1}$ boron for bread wheat and $12.4 \mathrm{mg} \mathrm{L}^{-1}$ boron for einkorn wheat. Our results indicated that einkorn wheat was more tolerant to boron stress than bread wheat. A previous study on in vitro of pear rootstock under salt-added boron stress showed that the number of plantlets decreased with the boron and salt amounts increased in culture media (Sotiropoulos et al. 2006). Genotype-boron stress factor was significant only in culture media containing control group and $0.5 \mathrm{mg} \mathrm{L}^{-1}$ BAP. The best plantlet number in bread wheat was in culture media containing 0.5 mg L 
BAP supplemented with $6.2 \mathrm{mg} \mathrm{L}^{-1}$ boron while control group containing $6.2 \mathrm{mg} \mathrm{L}^{-1}$ boron for einkorn wheat. Genotypes did not affect the number of plantlets.

Both wheat genotypes were transported to the soil. However, bread wheat succeeded the following period better. At the end of 38 days, nodes started to be seen only in bread wheat. At the end of the acclimatization period, flowering (60th days) and ripening (90th days) happened in bread wheat. Einkorn wheat did not form spike This may be an indication that bread wheat was better under acclimatization conditions.

\section{Conclusions}

Up to now, no studies have been reached, indicating efficient tissue culture protocol of einkorn (Triticum monococcum ssp. monococcum) and bread (Triticum aestivum) wheat via using mature embryo under different boron doses. Our study also revealed that hormone, genotype and boron affected both wheat species in vitro. It is important to point out that this report may help future in vitro studies of different wheat species or crops under boron stress conditions. Moreover, such effective tissue culture protocol may help for wheat improvement programs including breeding, genetic engineering, and genetic transformation.

\section{Declarations}

\section{Acknowledgements}

We would like to thank Bolu Abant İzzet Baysal University, Scientific Research Projects Fund (BAP - 2018.03.01.1296) for their financial contribution to this research.

\section{Disclosure statement}

No potential conflict of interest was reported by the author(s).

\section{References}

Abdel-Aal ES, Hucl P, Sosulski FW (1995) Compositional and nutritional characteristics of spring einkorn and spelt wheats. Cereal Chem 72:621-624

Aydın M., Sağsöz S, Haliloğlu K, Tosun M (2011) Factors affecting wheat mature embryo culture. Journal of the Faculty of Agriculture, Süleyman Demirel University 42(1):1-10.

Cartwright B, Zarcinas BA, Spuncer LR (1986) undefined Boron toxicity in South Australian barley crops. CSIRO

Cervilla LM, Blasco B, Ríos JJ, Rosales MA, Rubio-Wilhelmi MM, Sánchez-Rodríguez E, Romero L, Ruiz JM (2009) Response of nitrogen metabolism to boron toxicity in tomato plants. Plant Biol. (Stuttg). 11:671-677

Düzgüneş O, Kesici T, Kavuncu O, Gürbüz F (1987) Research and trial methods (Statistical Methods-II). Ankara University Faculty of Agriculture Publications: 1021, 381 pp. Ankara.

Fennell S, Bohorova N, Van Ginkel M, Crossa J, Hoisington D (1996) Plant regeneration from immature embryos of 48 elite CIMMYT bread wheats. Theor Appl Genet 92:163-169. https://doi.org/10.1007/BF00223371

Filippov M, Miroshnichenko D, Vernikovskaya D, Dolgov S (2006) The effect of auxins, time exposure to auxin and genotypes on somatic embryogenesis from mature embryos of wheat. Plant Cell Tissue Organ Cult 84:213-222. https://doi.org/10.1007/s11240-005-9026-6

Food and Agriculture Organization (FAO), Crops ttp://www.fao.org/faostat/en/\#data/QC, Accessed 14 Septemer 2020

Gupta UC, Jame YW, Campbell CA, Leyshon AJ, Nicholaichuk W (1985) Boron toxicity and deficiency: a review. Can J Soil Sci 65(3):381-409.

Hakkı EE, Atalay E, Harmankaya M, Babaoglu M, Hamurcu M, Gezgin S, Kampus KT (2007) Determination of suitable maize (Zea mays L.) genotypes to be cultivated in boron-rich Central Anatolian soil. In Plant and Animal Boron Nutrition. Wuhan, China: Springer, $231-247$.

Hammer K, Neumann M, Kison HU (1996) Pre-breeding work on einkorn-cooperation between gene bank and breeders. In: Padulosi S, Hammer K, Heller J (eds) Hulled wheats, promoting the conservation and used of underutilized and neglected crops. IPGRI, Rome, pp 198-202

Hess JR, Carman JG (1998) Embryogenic competence of immature wheat embryos: Genotype, donor plant environment, and endogenous hormone levels. Crop Sci 38:249-253. https://doi.org/10.2135/cropsci1998.0011183X003800010042x

Huang C, Graham RD (1990) Resistance of wheat genotypes to boron toxicity is expressed at the cellular level. Plant Soil 126:295-300.

https://doi.org/10.1007/BF00012832

Page 6/17 
Jabeen S, Khaliq I, Togo J, Sajjad M, ul Malook S (2016) Tissue Culture Technology is a Breeding Approach in Wheat: An Overview. Mol Plant Breed. https://doi.org/10.5376/mpb.2016.07.0013

Kalayci M, Alkan A, Çakmak I, Bayramoğlu O, Yilmaz A, Aydin M, Ozbek V, Ekiz H, Ozberisoy F (1998) Studies on differential response of wheat cultivars to boron toxicity. Euphytica 100:123-129. https://doi.org/10.1023/a:1018312124300

Kumar R, Mamrutha HM, Kaur A, Venkatesh K, Grewal A, Kumar R, Tiwari V (2017) Development of an efficient and reproducible regeneration system in wheat (Triticum aestivum L.). Physiol Mol Biol Plants 23:945-954. https://doi.org/10.1007/s12298-017-0463-6

Li W, Ding CH, Hu Z, Lu W, Guo GQ (2003) Relationship between tissue culture and agronomic traits of spring wheat. Plant Sci 164:1079-1085. https://doi.org/10.1016/S0168-9452(03)00113-4

Mahmood I, Razzaq A (2017) Responses of explant type of wheat (Triticum aestivum L.) genotypes to different tissue culture media. J Natl Sci Found Sri Lanka 45:265-271 . https://doi.org/10.4038/jnsfsr.v45i3.8191

Marschner H (1995) The soil root interface (rhizosphere) in relation to mineral nutrition. H. Marschner (Ed.), Mineral Nutrition of Higher Plants, Academic Press Ltd, London, pp. 537-595

Moore TC (1989) Biochemistry and physiology of plant hormones. Second Edt. Springer, New York.

Murin R, Mészáros K, Nemeček P, Kuna R, Faragó J (2012) Regeneration of immature and mature embryos from diverse sets of wheat genotypes using media containing different auxins. Acta Agron Hungarica 60:97-108. https://doi.org/10.1556/AAgr.60.2012.2.2

Nable RO, Bañuelos GS, Paull JG (1997) Boron toxicity. Plant Soil 193:181-198

Nasircilar AG, Turgut K, Fiskin K (2006) Callus induction and plant regeneration from mature embryos of different wheat genotypes. Pakistan J Bot 38:637-645

Örgeç M, Verma SK, Şahin G, Zencirci N, Gürel E (2021) In vitro tissue culture protocol of ancient einkorn (Triticum monococcum ssp. monococum) wheat via indirect shoot regeneration. Vitr Cell Dev Biol - Plant 57:143-151. https://doi.org/10.1007/s11627-020-10122-8

Örgeç M, Pehlivan Karakaş F, Şahin G, Ağıl F, Zencirci N (2018) Einkorn (Triticum monococcum ssp. monococcum) in vitro propagation sterilization protocol. Int J Second Metab 5:67-74. https://doi.org/10.21448/ijsm.399094

Özgen M, Türet M, Altinok S, Sancak C (1998) Efficient callus induction and plant regeneration from mature embryo culture of winter wheat (Triticum aestivum L.) genotypes. Plant Cell Rep 18:331-335. https://doi.org/10.1007/s002990050581

Özgen M, Türet M, Özcan S, Sancak C (1996) Callus induction and plant regeneration from immature and mature embryos of winter durum wheat genotypes. Plant Breeding 115(6), 455-458.

Papenfuss JM, Carman JG (1987) Enhanced Regeneration from Wheat Callus Cultures Using Dicamba and Kinetin 1. Crop Sci 27:588-593. https://doi.org/10.2135/cropsci1987.0011183x002700030035x

Parmar SS, Sainger M, Chaudhary D, Jaiwal PK (2012) Plant regeneration from mature embryo of commercial Indian bread wheat (Triticum aestivum L.) cultivars. Physiol Mol Biol Plants 18:177-183 . https://doi.org/10.1007/s12298-012-0101-2

Peng JH, Sun D, Nevo E (2011) Domestication evolution, genetics and genomics in wheat. Mol Breed 28:281-301 . https://doi.org/10.1007/s11032011-9608-4

Redway FA, Vasil V, Lu D, Vasil IK (1990) Identification of callus types for long-term maintenance and regeneration from commercial cultivars of wheat (Triticum aestivum L.). Theor Appl Genet 79:609-617 . https://doi.org/10.1007/BF00226873

Saha S, Islam Z, Islam S, Hassan MF, Hossain MS, Islam SMS (2017) Enhancement of Somatic Embryogenesis by Mature and Immature Seeds in Wheat (Triticum aestivum L.). J Biol Life Sci 8:20 . https://doi.org/10.5296/jbls.v8i2.11529

Satyavathi V V., Jauhar PP, Elias EM, Rao MB (2004) Effects of growth regulators on in vitro plant regeneration in durum wheat. Crop Sci 44:18391846 . https://doi.org/10.2135/cropsci2004.1839

Siddiqui MH, Al-Whaibi MH, Sakran AM, Ali HM, Basalah MO, Faisal M, Alatar A, Al-Amri AA (2013) Calcium-Induced Amelioration of Boron Toxicity in Radish. J Plant Growth Regul 32:61-71 . https://doi.org/10.1007/s00344-012-9276-6

Sotiropoulos TE, Fotopoulos S, Dimassi KN, Tsirakoglou V, Therios IN (2006) Response of the pear rootstock to boron and salinity in vitro. Biol Plant 50:779-781 . https://doi.org/10.1007/s10535-006-0130-1 
Suchowilska E, Wiwart M, Kandler W, Krska R (2012) A comparison of macro- and microelement concentrations in the whole grain of four Triticum species. Plant, Soil Environ 58:141-147 . https://doi.org/10.17221/688/2011-pse

Verma SK, Das AK, Cingoz GS, Uslu E, Gurel E 2016. Influence of nutrient media on callus induction, somatic embryogenesis and plant regeneration in selected Turkish crocus species. Biotechnol Reports 10:66-74 . https://doi.org/10.1016/j.btre.2016.03.006

Wrobel S 2009. Response of spring wheat to foliar fertilization with boron under reduced boron availability. J Elem 14:395-404.

https://doi.org/10.5601/jelem.2009.14.2.20

Yang S, Xu K, Wang Y, Bu B, Huang W, Sun F, Liu S, Xi Y 2015. Analysis of biochemical and physiological changes in wheat tissue culture using different germplasms and explant types. Acta Physiol Plant 37:1-10 . https://doi.org/10.1007/s11738-015-1861-4

Yorgancılar M, Babaoğlu M 2005. Investigation of the effect of boron on seed germination of wheat cultivars at in vitro and pot conditions. Selcuk Journal of Agriculture and Food Sciences 19(35):109-114.

Zale JM, Borchardt-Wier H, Kidwell KK, Steber CM 2004. Callus induction and plant regeneration from mature embryos of a diverse set of wheat genotypes. Plant Cell, Tissue and Organ Culture 76(3):277-281.

\section{Tables}

Table 1. Effects of different 2,4-D and Dicamba concentrations under boron stress on callus. 


\begin{tabular}{|c|c|c|c|c|c|c|c|c|c|c|c|}
\hline \multirow{4}{*}{$\begin{array}{l}\text { Genotypes } \\
\text { Einkorn ( } T \text {. } \\
\text { monococcum } \\
\text { sssp. } \\
\text { monococcum) } \\
\text { (IZA) }\end{array}$} & \multirow{2}{*}{$\begin{array}{l}\text { Boron } \\
\text { Concentrations } \\
\left(\mathrm{mg} \mathrm{L}^{-1}\right) \\
0\end{array}$} & \multirow{2}{*}{$\begin{array}{l}\text { Hormone } \\
\text { Types } \\
2,4-D\end{array}$} & \multirow{2}{*}{$\begin{array}{l}\text { Hormone } \\
\text { Concentrations } \\
\left(\mathrm{mg} \mathrm{L}^{-1}\right) \\
\text { Control }(0)\end{array}$} & \multicolumn{4}{|c|}{ Callus Weight (g)* } & \multicolumn{4}{|c|}{ Callus Diameter (cm)* } \\
\hline & & & & & - & & & & - & & \\
\hline & & & 1 & 2.57 & \pm & 0.38 & ghijklmn & 0.93 & \pm & 0.26 & jklmnop \\
\hline & & & 2 & 2.20 & \pm & 0.59 & mnopqrs & 0.84 & \pm & 0.34 & opqrstu \\
\hline & & & 4 & 2.59 & \pm & 0.76 & ghijklmn & 0.92 & \pm & 0.32 & klmnopqr \\
\hline & & Dicamba & Control (0) & & - & & & - & - & & \\
\hline & & & 1 & 3.10 & \pm & 0.53 & abcdefg & 1.01 & \pm & 0.39 & fghijkl \\
\hline & & & 2 & 3.50 & \pm & 0.30 & abcd & 1.00 & \pm & 0.32 & ghijklm \\
\hline & & & 4 & 2.70 & \pm & 0.26 & fghijklm & 0.87 & \pm & 0.27 & nopqrstu \\
\hline & 6.2 & $2,4-D$ & Control (0) & & - & & & & - & & \\
\hline & & & 1 & 3.54 & \pm & 0.35 & $a b c$ & 0.89 & - & 0.32 & Imnopqrstu \\
\hline & & & 2 & 3.03 & \pm & 0.55 & cdefghi & 0.80 & $I$ & 0.30 & stu \\
\hline & & & 4 & 2.88 & \pm & 0.60 & efghijkl & 0.92 & \pm & 0.31 & jklmnopq \\
\hline & & Dicamba & Control (0) & & - & & & & - & & \\
\hline & & & 1 & 3.71 & \pm & 0.13 & a & 0.94 & $I$ & 0.18 & jklmnop \\
\hline & & & 2 & 3.54 & \pm & 0.32 & abcd & 0.88 & \pm & 0.18 & mnopqrstu \\
\hline & & & 4 & 3.64 & \pm & 0.16 & $a b$ & 0.89 & \pm & 0.19 & Imnopqrstu \\
\hline & 12.4 & $2,4-D$ & Control (0) & & - & & & & - & & \\
\hline & & & 1 & 3.34 & \pm & 0.56 & abcde & 0.79 & \pm & 0.28 & u \\
\hline & & & 2 & 2.59 & \pm & 1.47 & ghijklmn & 0.87 & \pm & 0.27 & nopqrstu \\
\hline & & & 4 & 2.23 & \pm & 0.12 & mnopqrs & 0.91 & \pm & 0.33 & klmnopqrst \\
\hline & & Dicamba & Control (0) & & - & & & & - & & \\
\hline & & & 1 & 2.92 & \pm & 0.51 & defghijkl & 1.10 & \pm & 0.31 & bcdefgh \\
\hline & & & 2 & 2.43 & \pm & 0.46 & hijklmno & 1.01 & \pm & 0.28 & fghijk \\
\hline & & & 4 & 2.17 & \pm & 0.26 & mnopqrs & 1.02 & \pm & 0.31 & fghijk \\
\hline & 24.6 & $2,4-D$ & Control (0) & & - & & & & - & & \\
\hline & & & 1 & 2.57 & \pm & 0.26 & ghijklmn & 0.86 & \pm & 0.35 & opqrstu \\
\hline & & & 2 & 2.32 & \pm & 0.44 & klmnopqr & 0.85 & \pm & 0.31 & opqrstu \\
\hline & & & 4 & 2.29 & \pm & 0.69 & Imnopqr & 0.92 & \pm & 0.28 & jklmnop \\
\hline & & Dicamba & Control (0) & & - & & & & - & & \\
\hline & & & 1 & 2.02 & \pm & 0.39 & nopqrst & 1.02 & \pm & 0.25 & fghijk \\
\hline & & & 2 & 2.04 & \pm & 0.25 & nopqrst & 0.98 & \pm & 0.22 & hijklmn \\
\hline & & & 4 & 2.34 & \pm & 0.37 & jklmnopq & 1.02 & \pm & 0.22 & fghijk \\
\hline & 37.2 & $2,4-D$ & Control (0) & & - & & & & - & & \\
\hline & & & 1 & 2.32 & \pm & 0.24 & klmnopqr & 0.95 & \pm & 0.27 & ijklmno \\
\hline & & & 2 & 2.36 & \pm & 0.26 & jklmnopq & 0.88 & \pm & 0.29 & mnopqrstu \\
\hline
\end{tabular}


$\begin{array}{lllllll}1.99 & \pm & 0.17 \text { nopqrst } & 0.82 & \pm & & \end{array}$

Dicamba Control (0)

\begin{tabular}{llllllllll}
1 & 2.29 & \pm & 0.29 & Imnopqr & 1.06 & \pm & 0.26 & efghi \\
\hline 2 & 2.42 & \pm & 0.47 & hijklmnop & 1.08 & \pm & 0.27 & defgh \\
4 & 2.12 & \pm & 0.55 & mnopqrst & 1.01 & \pm & 0.30 & fghijk
\end{tabular}

Bread $\quad 0 \quad 2,4-D$
Wheat $(T$.
aestivum
L.) (cv
Tosunbey)

Control (0)

\begin{tabular}{lllllllll}
1 & 1.97 & \pm & 0.44 & nopqrst & 0.98 & \pm & 0.36 & hijklmn \\
\hline 2 & 2.14 & \pm & 1.02 & mnopqrst & 0.87 & \pm & 0.34 & nopqrstu \\
4 & 1.77 & \pm & 0.35 & pqrstuv & 0.88 & \pm & 0.29 & mnopqrstu
\end{tabular}

Dicamba Control (0)

$\begin{array}{lllllllll}1 & 2.60 & \pm & 0.40 & \text { ghijklmn } & 1.11 & \pm & 0.27 & \text { abcdefg } \\ 2 & 3.24 & \pm & 0.37 & \text { abcdef } & 1.17 & \pm & 0.28 & \text { abcd } \\ 4 & 3.04 & \pm & 0.59 & \text { bcdefgh } & 1.20 & \pm & 0.26 & \text { ab }\end{array}$

6.2

$2,4-D$

Control (0)

$\begin{array}{lllllllll}1 & 2.57 & \pm & 0.53 & \text { ghijklmn } & 0.95 & \pm & 0.30 & \text { ijklmno } \\ 2 & 2.15 & \pm & 0.54 & \text { mnopqrst } & 0.92 & \pm & 0.29 & \text { klmnopqrs } \\ 4 & 1.59 & \pm & 0.70 & \text { stuv } & 0.80 & \pm & 0.33 & \text { ru }\end{array}$

Dicamba Control (0)

\begin{tabular}{lllllllll}
1 & 2.14 & \pm & 0.19 & mnopqrst & 1.04 & \pm & 0.28 & efghij \\
\hline 2 & 2.96 & \pm & 0.27 & cdefghijk & 1.15 & \pm & 0.25 & abcde \\
4 & 3.23 & \pm & 0.39 & abcdef & 1.22 & \pm & 0.27 & a
\end{tabular}

12.4

2, 4-D

Control (0)

$\begin{array}{lllllllll}1 & 2.40 & \pm & 0.61 & \text { ijklmnop } & 0.88 & \pm & 0.26 & \text { mnopqrstu } \\ 2 & 2.00 & \pm & 0.51 & \text { nopqrst } & 0.78 & \pm & 0.25 & \text { u } \\ 4 & 1.53 & \pm & 0.59 & \text { tuv } & 0.80 & \pm & 0.30 & \text { qrstu }\end{array}$

Dicamba Control (0)

\begin{tabular}{lllllllll}
\hline 1 & 1.82 & \pm & 0.21 & opqrstu & 0.98 & \pm & 0.29 & hijklmn \\
\hline 2 & 2.58 & \pm & 0.47 & ghijklmn & 1.09 & \pm & 0.24 & cdefgh \\
\hline 4 & 3.46 & \pm & 0.40 & abcde & 1.19 & \pm & 0.37 & abc
\end{tabular}

24.6

Control (0)

\begin{tabular}{lllllllll}
\hline 1 & 2.24 & \pm & 0.69 & mnopqrs & 1.01 & \pm & 0.26 & fghijk \\
\hline 2 & 1.72 & \pm & 0.34 & qrstuv & 0.94 & \pm & 0.27 & jklmnop \\
\hline 4 & 1.33 & \pm & 0.30 & uv & 0.87 & \pm & 0.30 & nopqrstu
\end{tabular}

Dicamba Control (0)

\begin{tabular}{lcccccccc}
\hline 1 & 1.90 & \pm & 0.14 & opqrstu & 0.99 & \pm & 0.25 & hijklmn \\
\hline 2 & 2.43 & \pm & 0.30 & hijklmno & 1.06 & \pm & 0.25 & defghi \\
\hline 4 & 2.98 & \pm & 0.37 & cdefghij & 1.06 & \pm & 0.25 & efghi
\end{tabular}

Page 10/17 


\begin{tabular}{|c|c|c|c|c|c|c|c|c|c|c|}
\hline \multirow[t]{8}{*}{37.2} & \multirow[t]{4}{*}{$2,4-D$} & \multicolumn{2}{|l|}{ Control (0) } & \multicolumn{4}{|l|}{ - } & \multicolumn{3}{|l|}{-} \\
\hline & & 1 & 2.08 & \pm & 0.27 & mnopqrst & 0.93 & \pm & 0.27 & jklmnop \\
\hline & & 2 & 1.60 & \pm & 0.41 & stuv & 0.86 & \pm & 0.27 & opqrstu \\
\hline & & 4 & 1.20 & \pm & 0.62 & v & 0.79 & \pm & 0.28 & tu \\
\hline & Dicamba & Control (0) & & - & & & & - & & \\
\hline & & 1 & 1.68 & \pm & 0.17 & rstuv & 1.04 & \pm & 0.24 & efghij \\
\hline & & 2 & 2.23 & \pm & 0.23 & mnopqrs & 1.07 & \pm & 0.19 & defgh \\
\hline & & 4 & 2.61 & \pm & 0.22 & ghijklmn & 1.12 & \pm & 0.20 & abcdef \\
\hline
\end{tabular}

${ }^{*}$ Different letters indicate significant differences at $p<0.05$.

Table 2. Effects of different BAP concentrations under boron stress on regeneration capacity and plantlets number in mature embryo culture of wheat. 


\begin{tabular}{|c|c|c|c|c|c|c|c|c|c|c|}
\hline \multirow{3}{*}{$\begin{array}{l}\text { Genotypes } \\
\text { Einkorn (T. monococcum ssp. } \\
\text { monococcum) (IZA) }\end{array}$} & \multirow{2}{*}{$\begin{array}{l}\text { Boron } \\
\text { Concentrations (mg } \\
\left.\mathrm{L}^{-1}\right) \\
0\end{array}$} & \multirow{2}{*}{$\begin{array}{l}\text { Hormone Concentrations } \\
\left(\mathrm{mg} \mathrm{L}^{-1}\right)(\mathrm{BAP}) \\
\text { Control }(0)\end{array}$} & \multicolumn{4}{|c|}{$\begin{array}{l}\text { Regeneration Capacity } \\
(\%) *\end{array}$} & \multicolumn{4}{|c|}{ Plantlets Number $(n) *$} \\
\hline & & & 38.00 & \pm & 9.96 & eg & 2.13 & \pm & 1.03 & efgh \\
\hline & & 0.5 & 30.00 & \pm & 11.86 & fh & 2.58 & \pm & 0.83 & def \\
\hline & & 2 & 34.67 & \pm & 12.88 & $\mathrm{fg}$ & 2.92 & \pm & 0.88 & $\mathrm{~cd}$ \\
\hline & 6.2 & Control (0) & 71.33 & \pm & 11.78 & a & 2.79 & \pm & 0.78 & $c d$ \\
\hline & & 0.5 & 48.00 & \pm & 9.84 & ce & 2.71 & \pm & 0.81 & cde \\
\hline & & 2 & 56.67 & \pm & 12.27 & bc & 2.58 & \pm & 0.78 & def \\
\hline & 12.4 & Control (0) & 31.33 & \pm & 10.45 & fh & 3.08 & \pm & 0.83 & bcd \\
\hline & & 0.5 & 22.00 & \pm & 13.35 & hj & 2.04 & \pm & 0.95 & fghi \\
\hline & & 2 & 28.67 & \pm & 10.91 & $\mathrm{fi}$ & 2.63 & \pm & 0.71 & cdef \\
\hline & 24.6 & Control (0) & 18.00 & \pm & 12.97 & ik & 1.54 & \pm & 0.83 & hijk \\
\hline & & 0.5 & 14.67 & \pm & 10.80 & jl & 1.92 & \pm & 0.83 & ghij \\
\hline & & 2 & 13.33 & \pm & 11.76 & jl & 1.83 & \pm & 1.09 & ghijk \\
\hline & 37.2 & Control (0) & 14.67 & \pm & 12.88 & jl & 1.54 & \pm & 0.78 & hijk \\
\hline & & 0.5 & 8.00 & \pm & 9.32 & $\mathrm{kl}$ & 1.38 & \pm & 0.77 & $\mathrm{jk}$ \\
\hline & & 2 & 6.00 & \pm & 7.34 & Ip & 1.33 & \pm & 0.70 & $j k$ \\
\hline \multirow{15}{*}{$\begin{array}{l}\text { Bread Wheat (T. aestivum L.) (Cv. } \\
\text { Tosunbey) }\end{array}$} & 0 & Control (0) & 28.67 & \pm & 8.34 & $\mathrm{fi}$ & 3.17 & \pm & 0.92 & $a b c d$ \\
\hline & & 0.5 & 28.67 & \pm & 9.45 & $\mathrm{fi}$ & 3.21 & \pm & 1.18 & $a b c$ \\
\hline & & 2 & 28.00 & \pm & 11.68 & gi & 3.17 & \pm & 0.96 & $a b c d$ \\
\hline & 6.2 & Control (0) & 65.33 & \pm & 10.80 & $a b$ & 3.67 & \pm & 1.13 & a \\
\hline & & 0.5 & 46.00 & \pm & 10.16 & de & 3.71 & \pm & 1.12 & a \\
\hline & & 2 & 49.33 & \pm & 13.77 & $\mathrm{~cd}$ & 3.63 & \pm & 1.21 & $a b$ \\
\hline & 12.4 & Control (0) & 40.00 & \pm & 7.70 & df & 3.04 & \pm & 0.91 & $c d$ \\
\hline & & 0.5 & 34.00 & \pm & 6.63 & $\mathrm{fg}$ & 2.58 & \pm & 0.72 & def \\
\hline & & 2 & 34.00 & \pm & 9.66 & $\mathrm{fg}$ & 2.79 & \pm & 0.83 & $\mathrm{~cd}$ \\
\hline & 24.6 & Control (0) & 16.00 & \pm & 15.14 & jl & 1.67 & \pm & 0.96 & ghijk \\
\hline & & 0.5 & 7.33 & \pm & 5.84 & $\mathrm{kl}$ & 1.29 & \pm & 0.69 & k \\
\hline & & 2 & 16.00 & \pm & 11.84 & jl & 2.17 & \pm & 0.96 & efg \\
\hline & 37.2 & Control (0) & 20.00 & \pm & 10.89 & hj & 1.54 & \pm & 0.78 & hijk \\
\hline & & 0.5 & 15.33 & \pm & 6.33 & jl & 1.50 & \pm & 0.72 & $\mathrm{ijk}$ \\
\hline & & 2 & 22.00 & \pm & 14.76 & hj & 1.83 & \pm & 0.82 & ghijk \\
\hline
\end{tabular}

*Different letters indicate significant differences at $p<0.05$. 
Table 3. Analysis of variance of callus weights at $1 \mathrm{mg} \mathrm{L}^{-1} 2,4-\mathrm{D} / \mathrm{Dicamba}$ in mature wheat embryo.

\begin{tabular}{llllll} 
Source & Sum of Squares & Df & Mean Square & F & Sig. \\
\hline Genotypes & 12.236 & 1 & 12.236 & 77.218 & 0.000 \\
\hline Boron Stress & 10.466 & 4 & 2.616 & 16.513 & 0.000 \\
\hline Hormone Type & 0.509 & 1 & 0.509 & 3.217 & 0.076 \\
\hline Genotypes X Boron stress & 3.736 & 4 & 0.934 & 5.894 & 0.000 \\
\hline Genotypes X Hormone types & 0.164 & 1 & 0.164 & 1.040 & 0.310 \\
\hline Boron stress X Hormone types & 3.734 & 4 & 0.933 & 5891 & 0.000 \\
\hline Genotypes X Boron stress X Hormone types & 0.549 & 4 & 0.137 & 0.867 & 0.487 \\
\hline Error & 12.676 & 80 & 0.158 & &
\end{tabular}

Table 4. Analysis of variance of callus weights at $2 \mathrm{mg} \mathrm{L}^{-1}$ 2,4-D/Dicamba in mature wheat embryos.

\begin{tabular}{llllll} 
Source & Sum of Squares & df & Mean Square & F & Sig. \\
\hline Genotypes & 3.964 & 1 & 3.964 & 19.238 & 0.000 \\
\hline Boron Stress & 10.119 & 4 & 2.530 & 12.277 & 0.000 \\
\hline Hormone Type & 5.424 & 1 & 5.424 & 26.324 & 0.000 \\
\hline Genotypes X Boron stress & 1.310 & 4 & 0.328 & 1.590 & 0.185 \\
\hline Genotypes X Hormone types & 2.283 & 1 & 2.283 & 11.080 & 0.001 \\
\hline Boron stress X Hormone types & 4.796 & 4 & 1199 & 5818 & 0.000 \\
\hline Genotypes X Boron stress X Hormone types & 1.780 & 4 & 0.445 & 2.160 & 0.081 \\
\hline Error & 16.485 & 80 & 0.206 & &
\end{tabular}

Table 5. Analysis of variance of callus weights at $4 \mathrm{mg} \mathrm{L}^{-1}$ 2,4-D/Dicamba in mature wheat embryos.

\begin{tabular}{llllll} 
Source & Sum of Squares & df & Mean Square & F & Sig. \\
\hline Genotypes & 1.212 & 1 & 1.212 & 5.585 & 0.021 \\
\hline Boron Stress & 8.235 & 4 & 2.059 & 9.486 & 0.000 \\
\hline Hormone Type & 19.740 & 1 & 19.740 & 90.955 & 0.000 \\
\hline Genotypes X Boron stress & 3.382 & 4 & 0.846 & 3.896 & 0.006 \\
\hline Genotypes X Hormone types & 11.868 & 1 & 11.868 & 54.683 & 0.000 \\
\hline Boron stress X Hormone types & 0.776 & 4 & 0.194 & 0.894 & 0.471 \\
\hline Genotypes X Boron stress X Hormone types & 0.917 & 4 & 0.229 & 1.057 & 0.383 \\
\hline Error & 17.363 & 80 & 0.217 & &
\end{tabular}


Table 6. Analysis of variance of callus diameters at $1 \mathrm{mg} \mathrm{L}^{-1}$ 2,4-D/Dicamba in mature wheat embryos.

\begin{tabular}{llllll} 
Source & Sum of Squares & df & Mean Square & F & Sig. \\
\hline Genotypes & 0.372 & 1 & 0.372 & 4.587 & 0.032 \\
\hline Boron Stress & 0.693 & 4 & 0.173 & 2.134 & 0.075 \\
\hline Hormone Type & 3.170 & 1 & 3.170 & 39.032 & 0.000 \\
\hline Genotypes X Boron stress & 0.457 & 4 & 0.114 & 1.407 & 0.229 \\
\hline Genotypes X Hormone types & 0.210 & 1 & 0.210 & 2.589 & 0.108 \\
\hline Boron stress X Hormone types & 0.617 & 4 & 0.154 & 1901 & 0.108 \\
\hline Genotypes X Boron stress X Hormone types & 0.831 & 4 & 0.208 & 2.558 & 0.037 \\
\hline Error & 79.583 & 980 & 0.081 & &
\end{tabular}

Table 7. Analysis of variance of callus diameters at $2 \mathrm{mg} \mathrm{L}^{-1} 2,4-\mathrm{D} /$ Dicamba in mature wheat embryos.

\begin{tabular}{llllll} 
Source & Sum of Squares & df & Mean Square & F & Sig. \\
\hline Genotypes & 1.267 & 1 & 1.267 & 17.065 & 0.000 \\
\hline Boron Stress & 0.244 & 4 & 0.061 & 0.821 & 0.512 \\
\hline Hormone Type & 8.987 & 1 & 8.987 & 121.014 & 0.000 \\
\hline Genotypes X Boron stress & 1.512 & 4 & 0.378 & 5.090 & 0.000 \\
\hline Genotypes X Hormone types & 0.605 & 1 & 0.605 & 8.149 & 0.004 \\
\hline Boron stress X Hormone types & 0.393 & 4 & 0.098 & 1323 & 0.260 \\
\hline Genotypes X Boron stress X Hormone types & 0.331 & 4 & 0.083 & 1.115 & 0.348 \\
\hline Error & 72.779 & 980 & 0.074 & &
\end{tabular}

Table 8. Analysis of variance of callus diameters at $4 \mathrm{mg} \mathrm{L}^{-1} 2,4-\mathrm{D} / \mathrm{Dicamba}$ in mature wheat embryos. 


\begin{tabular}{llllll} 
Source & Sum of Squares & df & Mean Square & F & Sig. \\
\hline Genotypes & 1.011 & 1 & 1.011 & 12.380 & 0.000 \\
\hline Boron Stress & 0.214 & 4 & 0.054 & 0.656 & 0.623 \\
\hline Hormone Type & 9.565 & 1 & 9.565 & 117.098 & 0.000 \\
\hline Genotypes X Boron stress & 0.766 & 4 & 0.192 & 2.345 & 0.053 \\
\hline Genotypes X Hormone types & 4.303 & 1 & 4.303 & 52.684 & 0.000 \\
\hline Boron stress X Hormone types & 0.720 & 4 & 0.180 & 2204 & 0.067 \\
\hline Genotypes X Boron stress X Hormone types & 1138 & 4 & 0.285 & 3.483 & 0.008 \\
\hline Error & 80.048 & 980 & 0.082 & &
\end{tabular}

Table 9. Analysis of variance of plant regeneration capacity at three different BAP concentrations in mature wheat embryos.

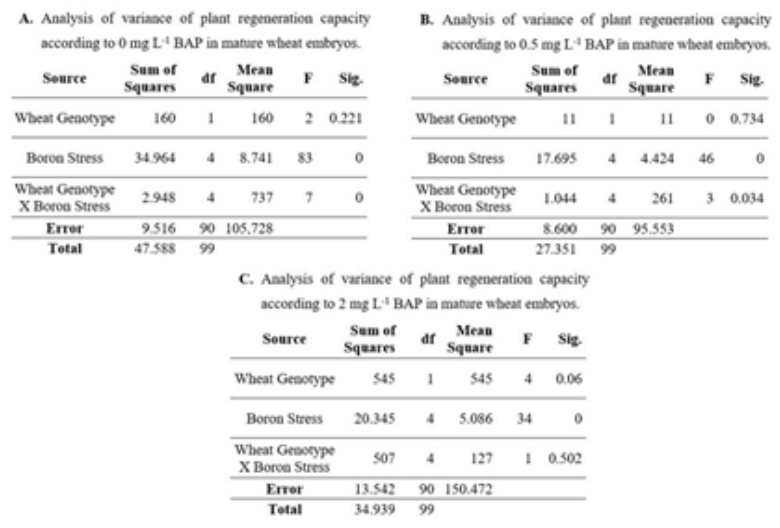

Table 10. Analysis of variance of plantlets numbers according to three different BAP concentrations in mature wheat embryos.

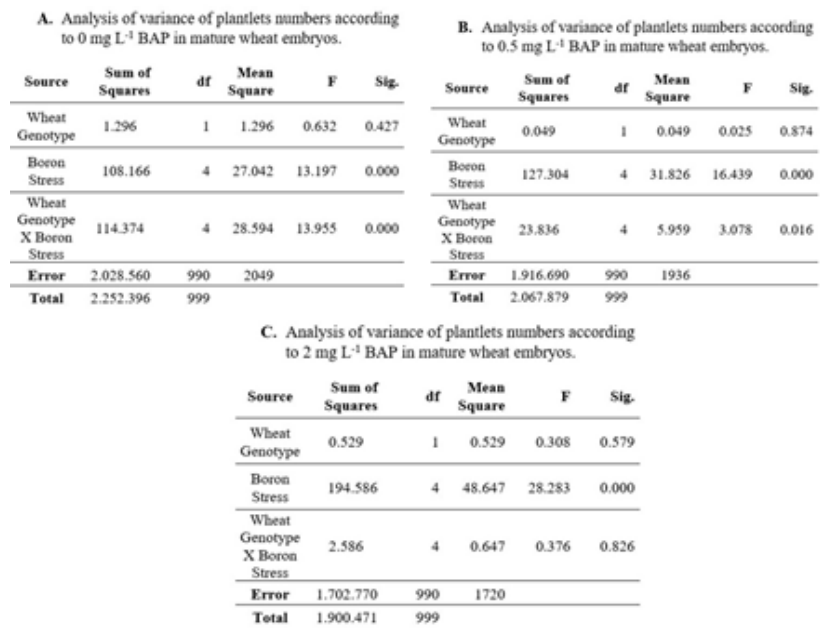

Figures 


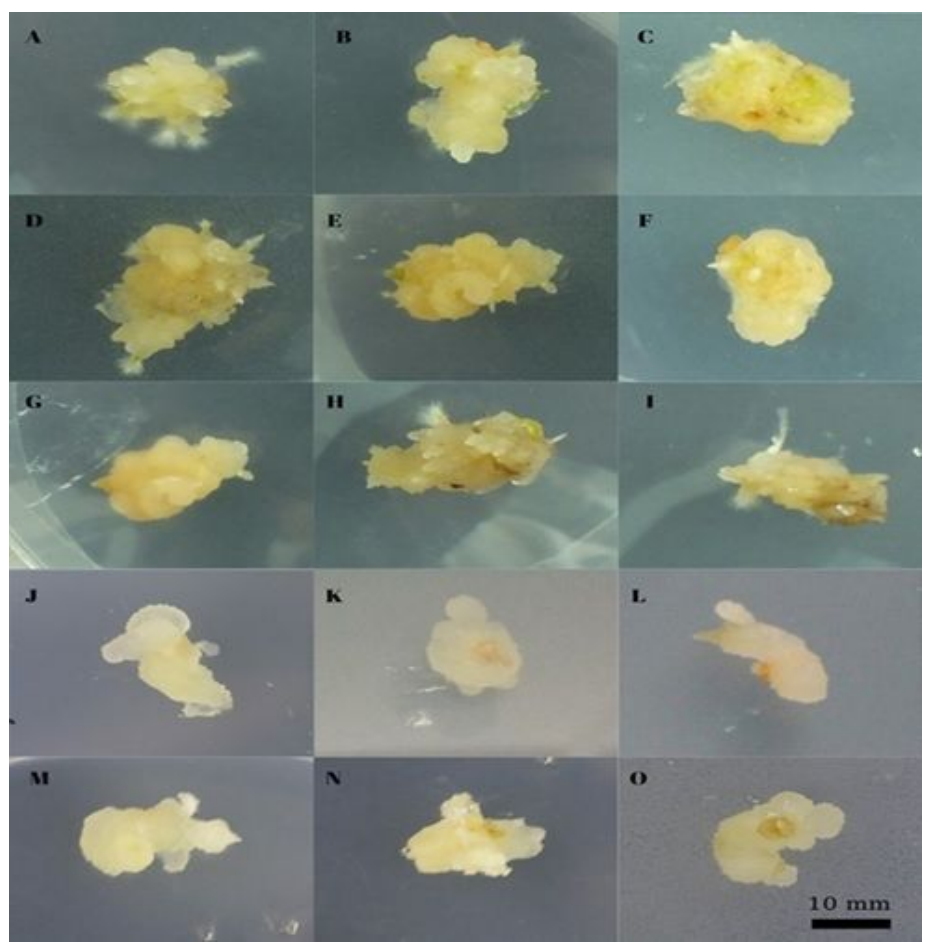

\section{Figure 1}

The effect of different 2,4-dichlorophenoxyacetic acid (2,4-D) and Dicamba concentrations under the different boron stresses on callus induction from mature embryos of einkorn and bread wheat. (A-I: Einkorn mature embryo, J-O: Bread mature embryo) A: 1 mg L-1 Dicamba, B: 2 mg L-1 1 Dicamba, C: 4 mg L-1 Dicamba (A, B and C under 0 mg L-1 Boron). D: 1 mg L-1 Dicamba, E: 2 mg L-1 Dicamba, F: 4 mg L-1 Dicamba (D, E and F under 6.2 mg L-1 Boron). G: 1 mg L-1 Dicamba, H: 2 mg L-1 Dicamba, l: 4 mg L-1 Dicamba (G, H and I under 12.4 mg L-1 Boron). J: mg L-1 2,4-D, K: 2 mg L-1 2,4-D, L: 4 mg L-1 2,4-D (J, K and L under 24.6 mg L-1 Boron). M: 1 mg L-1 2,4-D, N: 2 mg L-1 ,4-D, 0: 4 mg L-1 Dicamba (M, N and O under $37.2 \mathrm{mg}$ L-1 Boron)

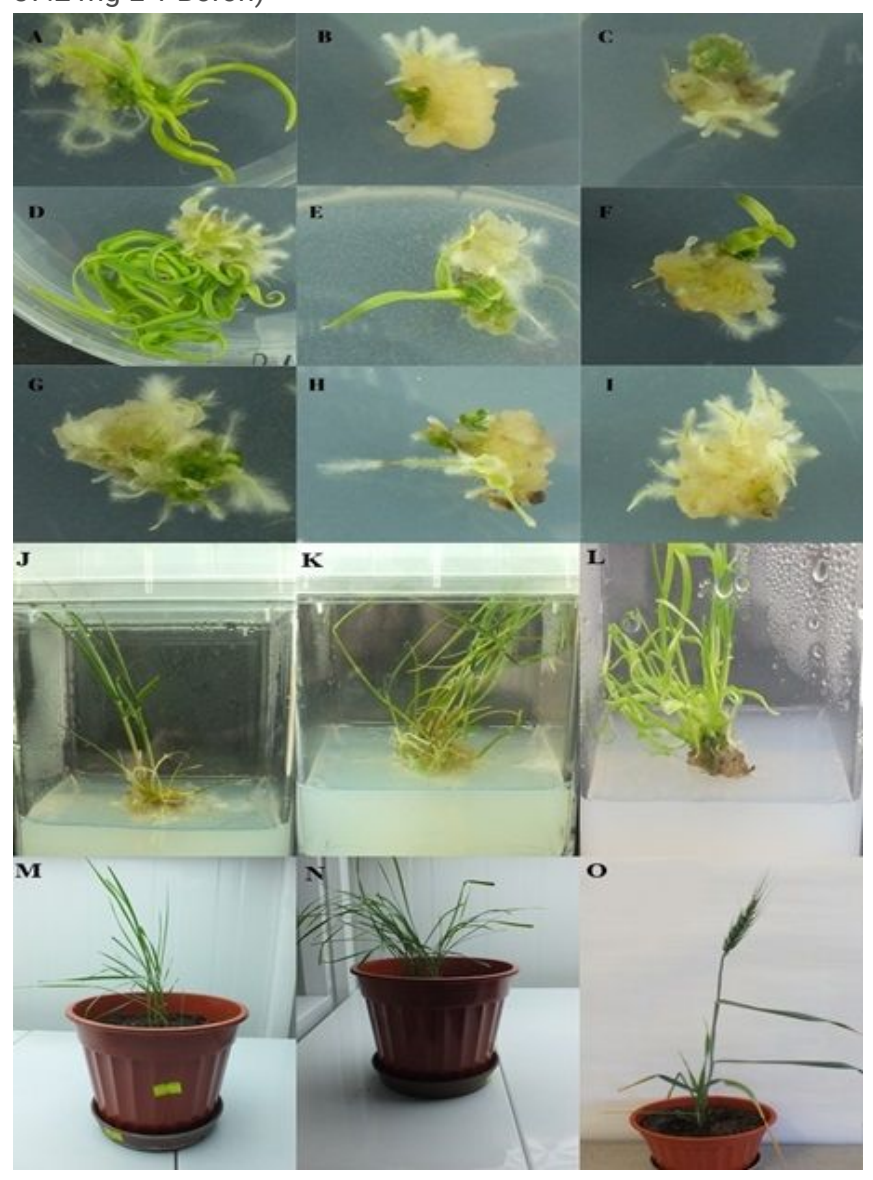




\section{Figure 2}

The effect of 6-Benzylaminopurine (BAP) under the different boron stresses on the plant regeneration from callus derived from mature embryos of einkorn and bread wheat. (A-l: Bread wheat) A: 0 mg L-1 BAP B: 0.5 mg L-1 BAP C:2 mg L-1 BAP (A, B and C under 0 mg L-1 Boron) D: 0 mg L-1 BAP E: 0.5 mg L-1 BAP F:2 mg L-1 BAP (D, E and F under 6.2 mg L-1 Boron) G: 0 mg L-1 BAP H: 0.5 mg L-1 BAP I: 2 mg L-1 BAP (G, H and I under 12.4 mg L-1 Boron) J: 0 mg L-1 BAP with 6.2 mg L-1 boron K: 2 mg L-1 BAP with 12.4 mg L-1 boron L: 2 mg L-1 BAP with 6.2 mg L-1 boron M: Transplanting regenerated einkorn wheat to soil $\mathrm{N}-\mathrm{O}$ : Transplanting regenerated einkorn wheat to soil
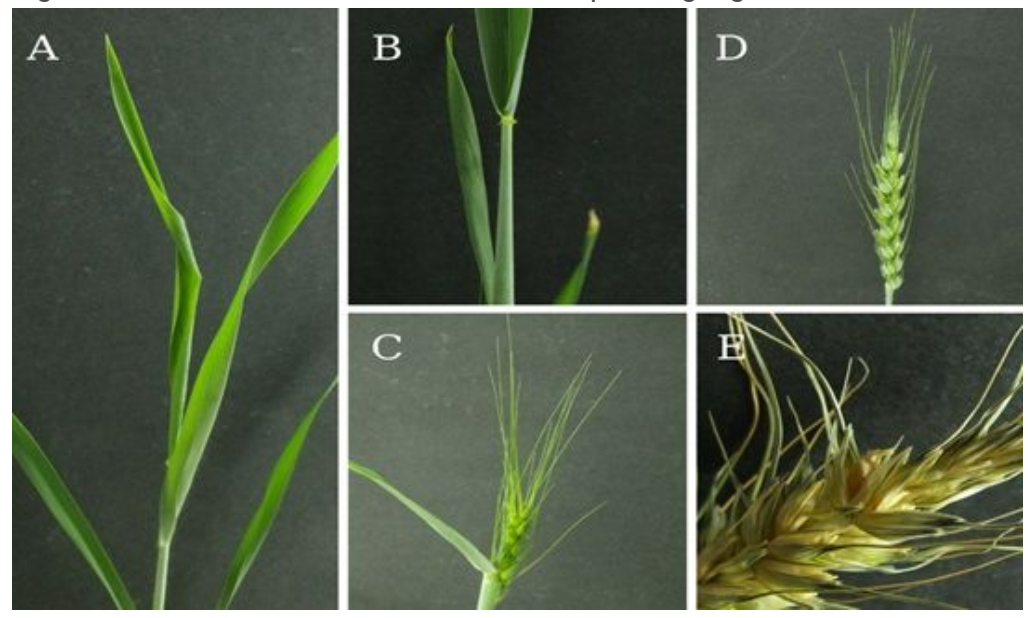

Figure 3

Spike development of bread wheat. 